\title{
Improving The Students' Cognitive Aspects In Oxy Acetylene Welding Course
}

\author{
Bernardus Agus Munadi ${ }^{1}$, Sunaryo Soenarto ${ }^{2}$ \\ ${ }^{1}$ Mechanical Engineering, SMK Negeri I Sayegan, Indonesia \\ Email: bagusmunadi@gmail.com \\ ${ }^{2}$ Technology and Vocational Education, Universitas Negeri Yogyakarta, Indonesia \\ Email: sunaryos@uny.ac
}

(Received: February-2019; Reviewed: April-2019; Accepted: June-2019; Published: August-2019)

\begin{abstract}
This study aims at improving learning activities and learning outcomes of cognitive aspects among $X$ grade students of Metal Fabrication Engineering and Manufacturing, Vocational High School (VHS) using Problem-Based Learning (PBL) method. This study used classroom action research, which was conducted in two cycles. Each cycle consisted of four stages, i.e. planning, implementation, observation, and reflection. This study involved one collaborator to assist researchers in implementing PBL and to monitor the learning process. The data collection technique used observation method with checklist and rating scale instrument. The data were analyzed descriptively. The results showed that the PBL implementation method in ignition system learning improve the students' learning activities with the percentage of $11.20 \%$, the learning activities, in which 29 students were in very high category and 3 students with high category. Also, the learning outcomes of cognitive aspects getting higher to $5.32 \%$ consisting of remembering (86.87\%), understanding (77.68\%), applying (78.77\%), analyzing (79.61\%), evaluation (77.97\%), and creating (79.16\%) respectively. Moreover, the students' learning outcomes raised of which 29 students (91.31\%) achieved above the minimum completeness criteria. It means that the PBL model can be used by vocational high teachers as alternative learning process to improve their outcomes of the cognitive aspects.
\end{abstract}

Keywords: problem-based learning; cognitive aspects; learning outcomes.

\section{INTRODUCTION}

The lack of education implementation in Vocational High Schools (VHS) has become a concern for the Indonesian government. The government keep trying to improve the quality of its learning process to achive the objectives of VHS education, i.e. to prepare students to enter the workforce in order to be able to compete in the current job market (Slamet, 2013). The subjects in VHS are divided into 3 groups, namely adaptive, normative and productive courses. According to Kurniasari, D., \& Isnani (2015), the graduates from vocational school are expected to have competitiveness opportunity to enter the business world/industry and expected to be able to prepare ready-made workers in community life. However, the target of vocational education to achieve high scores and to realized qualified learning process is still far from the target of national education standards and vision of 2025. The learning process seems not reflected a clear concept and principles that result in the low material mastery among VHS students (Sanjaya, 2011). Based on the observation in SMK Negeri I Sayegan (Vocational High School I Sayegan), one of courses that is considered diffilcult and complex is oxy acetylene welding. Moreover, the given evaluation from the teacher in the form of a test appears less effective to help the students' understanding, either the knowledge development or cognitive processes. In fact, most of students have been through their 
learning of oxy acetylene welding by having the practice process without any problem solving activities. The results of the previous semester in oxy acetylene welding course were still low.

Nowadays, there are many innovative and active teaching methods. Innovative teaching methods can effectively improve students' learning achievement (Sethi, V., Sethi V., \& Jeyaraj, 2017). As one of effective effort to improve this conditions, the learning process must be oriented to real world problems. The problem can be simplified related to the target of learning. Learning can be said successful if it implies the teaching and learning process which is able to improve students' learning activities and outcomes. The success of learning can be clarified from the students' competency in performing the acquired knowledge(Guthrie, J.W. \& Schuermann, 2011). One of the studentcentered learning approach that is able to enhance the learning process is problem-based learning (PBL). It is a method of learning which provides students with real problems so that students can enhance their knowledge and understanding through them (Liu, W. C., Liau, A. K., \& Tan, 2009). Astriani, et al. (2017) also find that the PBL model had a significant influence on the ability of problem solving.

A literature review showed that the roots of PBL are in the progressive educational movement which promoted more student involvement and engagement (Peterson, 2012). Besides, Ana, Sunarsih (2013) suggest that PBL model was effective to enhance students' generic green skills, such as project management, collaborative skills, and communicative competence. Thus, PBL should be put forward to overcome this situation. Reni \& Handaru (2018) points out that project-based learning has great potential in terms of learning material. Moreover, Raharjo (2018) clarifIES that this learning method challenges students to learn by working with the group to find solutions to real problems and those issues are used to enhance the sense of curiosity, critical ability and analysis upon the subject matter. It means PBL can affect students' social behavior (Febriana, 2017), as (Carrol, 1993) states that in such cases ability is defined in terms of maximal performance.

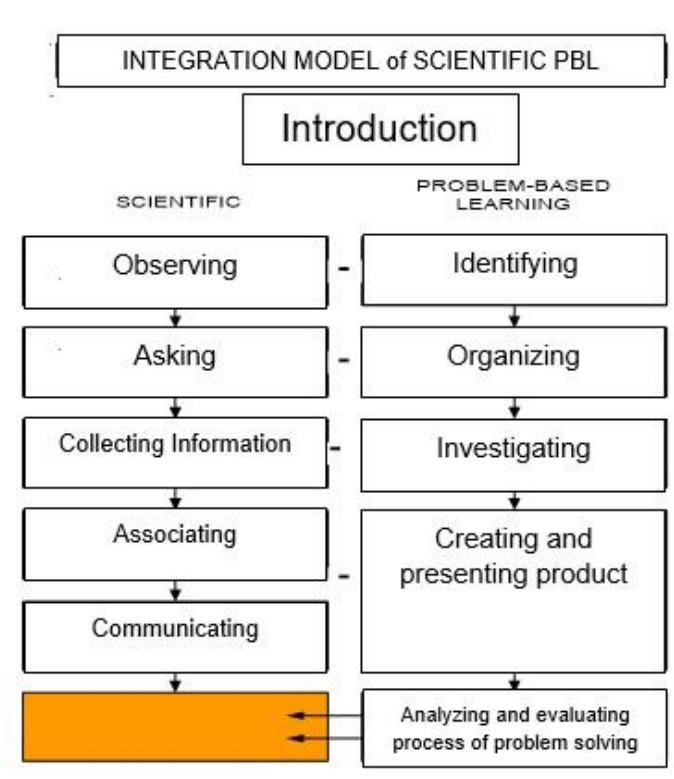

Figure 1. Integration model of scientific PBL

This study aimed at investigating the implementation of PBL to improve the learning outcomes of oxy-acetylene welding course SMK Negeri 1 Seyegan based on the 2013 curriculum. PBL is suitable to be run in the oxy acetylene welding learning in order to give the students real experience as a problem solver. The procedure of PBL is by discovering a problem designed by the teacher, then, students perform the learning process to find information from a variety of sources. It is followed by group discussions and make some investigation to gain the solution (Rusmono, 2012). Through those processes of PBL, the students are expected to find new knowledge (Barbara J. Duch, Susan E. Groh, 2001).

\section{METHOD}

The approach used in this study is a classroom action research with PBL model in order to improve the teaching and learning process and the programs and learning models that have been running in SMK Negeri I Sayegan. The steps include planning, action, observation, and reflection (Pardjono, 2007). In addition, the research design refers to Kemmis \& Mc. Taggart model. Taggart as according to the following picture: 


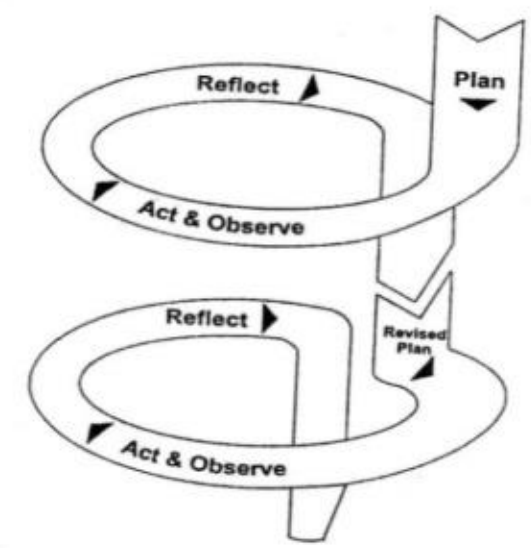

Figure 2. Kemmis \& Mc. TaggartDesign of Action Resreach

The data from this research were in the form of learning outcomes. It consisted of: cognitive aspects (knowledge) for oxyacetylene welding course. The cognitive aspects were obtained through two stages, namely, THE Pretest as to find out the initial abilities before PBL implementation, and the posttest as to find out the material mastery after PBL was applied in learning.

The research procedure of this Classroom Action Research procedure adapted from Kemmis and McTaggart models involving the stages of planning, implementation, observation, and reflection in each cycle. Every stage in the implementation of learning, the researcher worked with the oxy-acetylene welding teacher as a collaborator. The collaborators had a role as a learning implementation team with PBL method and they assisted the observations and assessment of the students' learning outcomes.

\section{RESULTS AND DISCUSSION}

\section{Results}

The study was conducted in two cycles. Each cycle included planning, Implementation, observation and reflection. The results and the discussion of this research was presented as follow. At this planning stage in cycle I, several items were prepared such as learning tools, lesson plans, teachers' activity instruments, students' activity instruments, problem-solving report sheets and experimental results, group discussion results sheets, pretest and cognitive test sheets, and student attendance lists.

There were 32 students involved in this study. The implementation of learning begian at
7:15 a.m. with the teacher conditioning the class by checking the attendance of students. It was followed by giving instruction for PBL implementation. This model was given to these students for their first time. So, they needed detailed explanations to achieve the learning objectives. Then, the delivery covering the learning devices filling by the students, observing the activities of the teachers and the mentors, small group divisions and the stages to carried out PBL model. Before the learning process, the students' ability was measured through the pretest. After that, the planned PBL method was implemented with 5 phases, as follow. The phase 1 was the students' orientation about the problem. The actions taken by the teacher were (a) explaining the learning purpose of oxy acetylene welding using PBL method; (b) explaining the stages of learning; (c) describing the equipment needed in PBL; and (d) motivating the students to be involved in activities to overcome the faced problems.

The learning objectives in this phase were to make the students able to understand: (a) the functions and components of oxy acetylene welding; (b) the working methods and principles of oxy acetylene welding; (c) the timing of ignition of oxy acetylene welding; (d) the components and methods of oxy acetylene working; and (e) the components and the working methods of oxy acetylene welding. The stages of learning that must be understood by students including (a) orienting students to problems; (b) organizing students to learn; (c) facilitating individual and group investigations; (d) developing and presenting the work; (e) analyzing and evaluating the problem solving process. The tools needed by the students in implementing PBL learning process include the oxy acetylene welding display unit, hand tools and measuring instruments, replacement components, guidebooks of oxy-acetylene welding, monitors and laptops with internet connectors. The main objective was to identify the problems that had been faced and equated the perception and ideas.

Phase 2 was facilitating the students to conduct an experiment. The teachers and collaborators acted as facilitators to assist the students in groups and individuals. The students discussed the stages of the steps to solve the problem they encountered. The purpose of this phase was to make the students able to actively 
conduct experiments and find information from relevant sources. The Phase 3 contained helping independent and group investigation. The result was each group reporting their investigation or the details of explanation for each solution to the problem as well as linking the theory to the fact according to the obtained information. Here, based on the observations results, some students still appeared to be passive during the learning implementation or lack of involvement in the experiments. In the first cycle, the students had already combined information in accordance with the measured components but they often asked questions to ensure their answer. It seemed that the student was not really confident with their own performance.

The observation showed that the students still found it difficult in determining the common cause of damage in the repairing step. They seemed to determine the damage without any logical reasons. The role of the teacher and collaborator was to help them to relate their logic with their faced problem, especially in each function and work of the oxy-acetylene welding component.

In Phase 4, it developed and presented the work. At this stage, each group was asked to develop and present their work in front of other groups and providing opportunities for other groups to contribute their ideas. The last phase was analyzing and evaluating the problem solving process. The eachers and collaborators facilitate the students to reflect on their investigations and the processes that had been carried out. The purpose of this activity was to review and evaluate their problem solving process based on the teacher's notes at the presentation. Learning activities using PBL required 3 (three) meetings with a total of 30 hours. The amount of time included the implementation of the five phases above. The time needed to complete a cognitive test was 60 minutes for 40 item questions. The cognitive question sheet consisted of (a) remembering; (b) understanding; (c) applying; (d) analyzing; (e) evaluating; and (f) creating. Those were arranged with different numbers in order to know the dominant area of the students' abilities. The cognitive aspect assessment was in the form of the escalation of the percentage after PBL implementation. Based on the results of the assessment in cognitive aspects, there was still no improvement on the basic competencies in learning. After the asessment was done, the second cycle was implemented since the students' activities and outcomes had not fulfilled yet. Meanwhile, the observation carried out on the teacher and student activities as well as the assessment of the students' cognitive / knowledge aspects

The results of cognitive assessment of the pretest before PBL implementation contained 6 (six) levels of cognitive aspect abilities with the number of 40 item questions. Each level was developed into a number of questions, such as: (a) remembering, with 5 items; (b) understanding with 7 items; (c) applying with 10 items; (d) analyzing with 10 items; (e) evauating with 4 items; and (f) creating with 4 items, respectively. The learning outcomes for cognitive aspects in the pretest is presented in the table 1 below.

Table 1. Assessment of cognitive aspect in the pretest of cycle I

\begin{tabular}{llccl}
\hline No. & $\begin{array}{l}\text { Level of } \\
\text { Cognitive } \\
\text { Ability }\end{array}$ & $\begin{array}{c}\text { Item } \\
\text { Number }\end{array}$ & Completeness & $\begin{array}{l}\text { Mean } \\
(\%)\end{array}$ \\
\hline 1 & Remembering & 5 & 2 & 58,97 \\
2 & Understanding & 6 & 2 & 63,81 \\
3 & Applying & 9 & 2 & 57,11 \\
4 & Analyzing & 11 & 3 & 52,44 \\
5 & Evaluating & 4 & 0 & 58,33 \\
6 & Creating & 4 & 0 & 55,13 \\
& Total & $\mathbf{4 0}$ & $\mathbf{9}$ & $\mathbf{6 1 , 7 2}$ \\
\hline
\end{tabular}

The data on the pretest on cognitive aspects above showed the overall mean score of $61.72 \%$ from 40 questions with 9 items completness. The details of the learning outcomes were: (a) considering with $58.97 \%$ by having 5 questions of which 2 completed; (b) understanding with $63.81 \%$ by having 7 items of which 2 completed; (c) applying consisting of $57.11 \%$ with 9 questions of which 2 completed; (d) analyzing by having 52.44\% with 11 of which 3 completed; (e) assessing attaining $58.33 \%$ of which 4 not completed yet; and (f) creating by having $55.13 \%$ with 4 not completed items. From 32 students, it was 6 students (15.4\%) who obtained the score above the minimum completeness criteria of 70 . The learning outcomes of cognitive aspects on posttests after the learning process was completed presented in the table 2 : 
Table 2. Assessment of cognitive aspect on posttest of cycle I

\begin{tabular}{llccc}
\hline No. & $\begin{array}{l}\text { Level of } \\
\text { Cognitive } \\
\text { Ability }\end{array}$ & $\begin{array}{c}\text { Item } \\
\text { Number }\end{array}$ & Completeness & Mean (\%) \\
\hline 1 & Remembering & 5 & 4 & 73,21 \\
2 & Understanding & 6 & 5 & 79,52 \\
3 & Applying & 9 & 6 & 70,32 \\
4 & Analyzing & 11 & 9 & 76,16 \\
5 & Evaluating & 4 & 2 & 72,47 \\
6 & Creating & 4 & 3 & 69,15 \\
& $\quad$ Total & $\mathbf{4 0}$ & $\mathbf{2 9}$ & $\mathbf{7 3 , 8 3}$ \\
\hline
\end{tabular}

Reflection was the final stage in each action. It was done to assess the research that had been carried out and to decide wheter it still needed some improvement. The learning outcomes of cognitive aspects on posttest after PBL implementation showed the percentage of $73.83 \%$, with details as follows: (a) considering 1 (73.21\%); (b) understand (79.52\%); (c) applying 2 (70.32\%); (d) analyzing (76.16\%); (e) 3 evaluating (72.17\%); and (f) creating (69.15\%) respectively. Based on the above percentage of ${ }_{5}$ the students who have completed the minimum completeness criteria as many as 27 students $(74.19 \%)$. Meanwhile, the indicator of success was the student completeness with $80 \%$. The cognitive learning had not met the expected target yet, so it needed to be improved in the cycle II.

In the planning stage of cycle II, the researcher prepared the learning devices consisting of in depth lesson plan according to the reflection from the first cycle. The class meeting was opened and the students was conditioned. It was followed by chacking the students' attendance of. After that, the researcher conveyed the results of the first cycle and gave direction for better PBL learning in the second cycle. The researcher explained the purpose of oxy acetylene welding learning using the PBL method in cycle II. Before learning took place, the students were given a pretest sheet to measure their initial abilities before the $\mathrm{No}_{\mathrm{N}}$ learning and they worked according to the instructions. Next, the researcher instructed the students to make groups and worked within the ${ }^{2}$ divided groups. The learning process referred to ${ }_{4}^{3}$ the lesson plan by emphasizing the 5 improvements in the first cycle in order to ${ }^{6}$ anticipate the deficiencies in cycle It. Meanwhile, the observation carried out on the teacher and student activities as well as the assessment of the students' cognitive or knowledge aspects.

Data on the results of cognitive assessment of the pretest in cycle II before PBL implementation contained 6 (six) levels of cognitive aspect abilities with the number of 40 item questions. Each level was developed into a number of questions, such as: (a) remembering, with 5 items; (b) understanding with 6 items; (c) applying with 9 items; (d) analyzing with 11 items; (e) evauating with 5 items; and (f) creating with 4 items, respectively. The learning outcomes for cognitive aspects in the pretest is presented in the table 3 below.

Table 3. The Assessment of cognitive aspect in cycle II

\begin{tabular}{lccc}
$\begin{array}{l}\text { Level of } \\
\text { Cognitive } \\
\text { Ability }\end{array}$ & $\begin{array}{c}\text { Item } \\
\text { Number }\end{array}$ & Completeness & Mean (\%) \\
\hline Remembering & 5 & 4 & 72.69 \\
Understanding & 6 & 5 & 64.28 \\
Applying & 9 & 6 & 62.33 \\
Analyzing & 11 & 9 & 68.88 \\
Evaluating & 4 & 2 & 70.28 \\
Creating & 4 & 3 & 71.78 \\
\multicolumn{1}{c}{ Total } & $\mathbf{4 0}$ & $\mathbf{2 9}$ & $\mathbf{7 1 . 0 4}$ \\
\hline
\end{tabular}

The learning outcomes data above showed that the overall score was $56.41 \%$ (22 students) of 32 students. The learning outcomes based on the minimum completeness criteria of 70. The ability of cognitive aspects that had not been completed was understanding and applying. The results was much better because the students had already learned the material from the first cycle, so there as some improvement. The results of learning outcomes of cognitive aspects in cycle II presented in table 4 below.

Table 4. The Assessment of cognitive aspect of postest in cycle II

\begin{tabular}{lccc}
$\begin{array}{l}\text { Level of } \\
\text { Cognitive } \\
\text { Ability }\end{array}$ & $\begin{array}{c}\text { Item } \\
\text { Number }\end{array}$ & Completeness & Mean (\%) \\
\hline Remembering & 5 & 5 & 86,87 \\
Understanding & 6 & 4 & 77,68 \\
Applying & 9 & 9 & 78,77 \\
Analyzing & 11 & 9 & 77,79 \\
Evaluating & 5 & 3 & 76,97 \\
Creating & 5 & 5 & 75,96 \\
\multicolumn{1}{c}{ Total } & $\mathbf{4 0}$ & $\mathbf{3 4}$ & $\mathbf{7 9 , 6 5}$ \\
\hline
\end{tabular}


The learing results from the posttest in cycle II for cognitive aspects showed an increased by $9.61 \%$ compared to the pretest results. The indicators of posttest for cognitive abilities had been fulfilled the minimum completeness criteria of 70 with the percentage of $80 \%$. It indicated the cognitive aspect learning was declared achieved or fulfilled.

The reflection stage in cycle II was done to review the learning that had been well implemented and it seemed that the result was not good enough. The implementation of cognitive aspects tests in the second cycle was carried out two times, before learning was carried out to know the students' initial abilities and after PBL learning to find out the improvement of students' learning outcomes. The learning outcomes of cognitive aspects, both pre-test and post-test, were specified based on cognitive abilities. The learning mastery was determined by the success achieved in the posttest, while the cognitive aspects of posttest ability data presented as follows: (a) considering (86.87\%); (b) understand (77.68\%); (c) applying (78.77\%); (d) analyzing (79.61\%); (e) assessing (77.97\%); and (f) creating (79.16\%) respectively. The percentage of average score was $79.8 \%$. The students above the minimum completness criteria were 29 students $(93.42 \%)$ out of 32 students. The success of learning was that the students completed the basic competencies manifested in the assessment results. Based on the cognitive aspect data above, it was concluded that student learning outcomes in cognitive abilities had been improved.

The tests to measure cognitive aspects in the second cycle was carried out 2 times, i.e. before learning was carried out to know the students' initial abilities and after PBL learning to find out the improvement of students' learning outcomes. The learning outcomes of the cognitive aspects, both pre-test and post-test, were specified based on the cognitive abilities. The mastery of learning was determined by the accomplishment in the posttest. The posttest results for cognitive aspects are as follows: (a) considering (86.87\%); (b) understanding (77.68\%); (c) applying (78.77\%); (d) analyzing (79.61\%); (e) evaluating (77.97\%); and (f) creating $(79.16 \%)$ respectively. The average percentage was $79.8 \%$ and the students who obtained above the minimum completeness criteria were 29 students $(93.42 \%)$ out of 32 students. The success of the learning can be seen from the students' completeness in their basic competencies in the assessment results. Based on the cognitive aspect data above, it was concluded that the student learning outcomes in cognitive abilities had been achieved.

\section{Discussion}

This classroom action research was carried out in two cycles with a total of 3 (three) meetings for each cycle. The implementation included the learning activities and the achievement of learning outcomes. The success or failure of learning by applying PBL can be analyzed based on the student learning outcomes. The ability of student learning outcomes covered cognitive, psychomotor and affective aspects. The assessments of learning outcomes were done before and after the application of PBL. In the beginning of learning, it was in the form of the initial ability before PBL implementation, while the cognitive, psychomotor and affective aspects were revealed after the learning implementation. The test assessing learning outcomes was carried out in two stages, cycle I and cycle II. The obtained learning outcomes by the students after applying PBL can be explained in Table 5 .

Table 5. The escalation of Cognitive Aspect in the Students Pretest and Posttest

\begin{tabular}{llcccc}
\hline & \multirow{2}{*}{$\begin{array}{c}\text { Level of } \\
\text { No. }\end{array}$} & \multicolumn{2}{c}{ Cycle I } & \multicolumn{2}{c}{ Cycle II } \\
& $\begin{array}{c}\text { cognitive } \\
\text { ability }\end{array}$ & $\begin{array}{c}\text { Pre-test } \\
(\%)\end{array}$ & $\begin{array}{c}\text { Post- } \\
\text { test } \\
(\%)\end{array}$ & $\begin{array}{c}\text { Pre-test } \\
(\%)\end{array}$ & $\begin{array}{c}\text { Post- } \\
\text { test } \\
(\%)\end{array}$ \\
\hline 1 & Remembering & 58.97 & 73.21 & 72.69 & 86.87 \\
2 & Understanding & 63.81 & 79.52 & 64.25 & 77.68 \\
3 & Applying & 57.11 & 70.32 & 62.33 & 79.77 \\
4 & Analyzing & 52.44 & 76.16 & 68.88 & 79.91 \\
5 & Evaluating & 58.33 & 72.17 & 70.26 & 79.97 \\
6 & Creating & 55.23 & 69.15 & 71.78 & 78.46 \\
& Total & $\mathbf{6 1 . 7 2}$ & $\mathbf{7 3 . 8 3}$ & $\mathbf{7 1 . 0 4}$ & $\mathbf{8 0 . 4 4}$ \\
\hline
\end{tabular}

The improvement of learning outcomes for the cognitive aspects in the second cycle was related to the mastery improvement in the implementation of PBL learning. In addition, in cycle II, the students were actively involved in implementing PBL. The improvement of students' involvement also stimulate the improvement of the students' material mastery. This findings in line with Raharjo (2018) study that found PBL method can stimulate motivation during the learning which is ultimately able to improve the students' learning outcomes. It is also similar to the previous studies that decide that PBL concerns more on active student 
participation in the learning (Liu, W. C., Liau, A. K., \& Tan, 2009)

\section{CONCLUSION AND SUGGESTION}

Based on the results of the research, some conclusions can be drawn as follow (1) PBL as the problem-based learning strategy in the real world can be used to stimulate the students' critical thinking in solving problems. (2) PBL is students' centered in which teacher play a role to facilitate and support students in solving problems and collecting all knowledge that students have. (3) At first, the learning outcomes for the students' cognitive aspects was $29.06 \%$ and after PBL method in the first cycle increased to $56.88 \%$ and became $84.77 \%$ in the second cycle. The escalation between cycles I and II was $27.89 \%$ after the implementation of PBL. It means PBL method can improve learning activities and the learning outcomes of the students' cognitive aspects.

Therefore, the PBL model based on the surrounding environment can be used by the vocational high teacher as an alternative learning process to improve their outcomes of the cognitive aspects. The study on PBL can also be developed in other learning contents or as beneficial reference for future research.

\section{REFERENCES}

Ana, Sunarsih, N. R. (2013). Pengembangan Tugas Akhir melalui Project Based Learning Model untuk Meningkatkan Generic Green Skills Siswa. Jurnal Pendidikan Teknologi Dan Kejuruan, 21(3), 219-226.

Astriani, N., Edy,S.,\& Edi, S. (2017). The Effect of Problem Based Learning to Students' Mathematical Problem Solving Ability. International Journal of Advance Research and Innovative Ideas in Education, 3(1), 3441-3446.

B., C. J. (1993). Human cognitive abilities: a survey of factor-analytic studies. New York: Cambridge University Press.

Barbara J. Duch, Susan E. Groh, D. E. A. (2001). The Power Of Problem Based Learning. Virginia: Stylus.

Febriana, R. (2017). The Effectiveness of Project Based Learning on Students' Social Attitude and Learning Outcomes.
Jurnal Pendidikan Teknologi Dan Kejuruan, 23(4), 374-382.

Guthrie, J.W. \& Schuermann, P. J. (2011). Leading Schools to Succes: Constructing and Sustaining High Performing Learning Culture. Los Angeles: SAGE Publication, Inc.

Kurniasari, D., \& Isnani, G. (2015). Analysis of Implementation of the World Cooperation SMK Enterprises/Analisis Pelaksanaan Kerjasama SMK dengan Dunia Usaha. Jurnal Pendidikan Bisnis Dan Manajemen, l(1), 24-33.

Liu, W. C., Liau, A. K., \& Tan, O. S. (2009). EPortfolios for Problem-Based Learning: Scaffolding Thinking and Learning in Preservice Teacher Education. In Tan, O.S. (Ed.). Problem-Based Learning and Creativity. Singapore: Cengage Learning Asia Pte Ltd.

Pardjono, E. al. (2007). Panduan penelitian tindakan kelas. Yogyakarta. Yogyakarta: Lembaga Penelitian Universitas Negeri Yogyakarta.

Peterson, B. W. (2012). Uncovering the Progressive Past: The Origins of Project Based Learning. A Journal of Adult Learning in Schools.

Raharjo. (2018). The influence of problembased learning and direct Teaching on students' learning outcomes. Jurnal Pendidikan Teknologi Dan Kejuruan, 24(1), 62-71.

Reni \& Handaru. (2018). Project-Based Electronic Module Development as A Supporting Learning Media For Basic Programming Learning. Journal of Educational Science and Technology, 4(3), 221-227.

Rusmono. (2012). Strategi Pembelajaran Dengan Problem Based Learning. Bogor: Ghalia.

Sanjaya, W. (n.d.). Pembelajaran dalam Implementasi Kurikulum Berbasis Kompetensi. Jakarta: Kencana.

Sethi, V., Sethi V., \& Jeyaraj, A. (2017). Enabling Context-based Learning with 
99 | Vol 5 No 2, August 2019

KPortal Webspace Technology. The Journal of Effective Teaching, 17(3), 3858.

Slamet. (2013). Pengembangan SMK Model untuk Masa Depan. Cakrawala Pendidikan, 32(1), 14-26. 